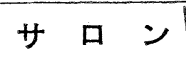

\title{
低温電力国際会議に出席して
}

低温電力国際会議 (Conference on Low Temperatures and Electric Power) が, 国際冷凍協会の 第一部会 (Commission 1 of the International Institute of Refrigeration) と英国極低温協会 (The British Cryogenics Council) との共催の下に, 昭 和44年 3 月 24 日より 27 日までの 4 日間ロンドンで開催 された。このらち 3 日間は講演会で, 1 日が見学会で あった。小生はこの会議に出席する機会を得たが, 会 議の内容は世界の共通課題として, わが国でも今後真 剣付討議されるべきものと考えるので, 会議の様子を 紹介し関係者の参考に供することにしたい。

世界の電力需要の増大は年 $7 \%$ の割で伸びており, 今後も引き続き可成り高度の伸びを続けるものと考え られる。したがって 21 世紀初頭には現在の10倍の電力 需要が女ると予想される。このような大きな伸び率の 電力を安定して供給孛確保するに, 現技術の延長でい いのかははなはだ疑問であり, 発電, 送電の両面に亘 って大きな飛躍が望まれる。超電導はこのような意味 に扔いて未来技術の担い手として十分な資格をもつも のであり，今回の会議はまことに時宜を得た計画であ った。事実多数の講演者より未来の電力システムでの 超電導技術の役割が述べられた。

会議は前記のように2 協会の共催で開かれたが, 議 事題目が電力関係であるので, 英国電気学会関係者が 会議の進行に当るなど有力に後援していた。会議の組 織メンバーの議長はオックスホード大学の Prof，N. Kurti であるが, これに英国の機器, ケーブル, 冷凍 機, 金属の各メ一カー, 使用者側の英国電力公団, 海 外から CGE (仏), フイリップス(和)を加えるなど広 範囲に各界の代表者が集められ，会議の内容が偏らな いよう十分な配慮が行なわれていた。会場は中心街の ピカデリ・サーカスにほど近い王立協会で, 参加者は 米ソを始め世界の多数の国々より百余名が参加した。

会議は国際低温協会第一部会の会長 Dr.J.Wilks の挨拶で始まった。講演は予め主催者側の用意した総

*東芝鶴見工場電機技術研究所
山本充 義*

括的な特別講演と一般からの応募で集った普通講演と

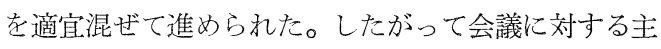
催者側の意図, 議事内容は特別講演を知れば大凡を知 ることができるので，その概要を述べ，また普通講演 に対しては一般的傾向ならびに注目す心゙き論文につい て二三ふれることにする。特別講演の題目は下記に示 寸通りである。

\section{(1) 特別講演の内容}

(a) Problems of the Electrical Power Industry

A. Chorlton(Central Electricity Generating Board, U.K.)

(b) Problems of Large-Scale Refrigeration Ch. Trepp(Sulzer Brs, Ltd, Winterthur, Switzerland)

(c) Cryogenics Transmission

S.H. Minnich and GR. Fox (G.E., U. S.A.)

(d) A.C. Losses in Superconductors

B.B. Goodman (British Oxygen Co., U. K.)

(e) Motors, Generators and Flux Pumps

A.D. Appleton (IRD Co., U.K.)

(f) Material

P.H. Burnier (Alsthom, France)

(g) Consideration of the future of Cryoelectricity in the Electrical Energy Industry

J. Fabre (Electricite de France)

上記題目で始めと終りに電力の未来像を置き, その 各々に英仏の大物に講演させているのは, 電力への超 電導の応用が如何に意欲的であるかが解る。

(a)で, Chorlton 法英国の電力系統は高電力密度化 と高性能化を行なう必要があり, これには現交流送電 系はもちろん, 新しく導入する直流送電系に対しても 広籁囲にケーブル化することになるが，ここに超電導 ケーブルを考慮すべきだと述べた。(g)の Fabre は超 
電導電気工学は電力系統, 電気機器に革命的な変化を もたらすよらに思われるが，これは経済的な面も十分 検討すべきだと警告した後, 仏国の電力系統を論じ, 20 年後には $220 \mathrm{kV} \times 4$ 回線よりほ超電導 1 回線の方が 有利になるだらうと注目すべき発言を行なった。なお このためには保護, 交流損の問題は着実に研究を重㸚 るべきだとも述べた。超電導マグネットを揚水発電所 の代りにエネルギ一蓄積装置として使用寸る課題に対 しては興味亦る問題だが，今後の開発状況と原子力の 発展との競争になるだらうと語った。(c)で, Minnich は超電導ケーブルとクライオケーブル（超電導まで行 かず極低温で使用するケーブル), 現用ケーブルの比較 走行なった。液体水素, 液体窒素法絶縁油以上に良好 な絶縁特性をもつので，油の代りに上記液体を使用し たケーブルが考えられる。なお, 純度の高いアルミニ ウムの電気抵抗は, 液体水素温度 $\left(20^{\circ} \mathrm{K}\right)$ で注常温の それの 500 2, 000 分の 1 となることも有利な条件と なる。この種ケーブルは泠却効辫がまだ比較的によい $20^{\circ} \mathrm{K}$ (液体水素) または $77^{\circ} \mathrm{K}$ (液体空素）を使用す るため，渦流損乞の他を含めても交流損失の冷却は可 能で,使用条件にもよるが,場合によっては現用ケーブ ルとか超電導ケーブルより有利なことがあるといらの が Minnich の主張である。一般講演で英国の BICC 社の Roger らが，クライオケーブルは超電導ケーブ ル㹥もちろん現用ケーブルよりも経済的に劣ると発表 したので, Minnich とRoger との間で議論が沸とう した。結局はいすれも十分な経験に基づいたものでな マので物分れに終った。今後米国のクライオケーブル と英国の超電導ケーブルとの間に議論が続くものと考 えられる。現在のケーブルでも欧州は OF ケーブル， 米国では压力パイプケーブルが使用されておら，この 場合にも実用段階では違った形熊のものになるかは今 後興味のあるところである。

(e)で Appleton が超電導機器の世界での開発状況, その未来像について述べた。現在この種機器は日, 米,

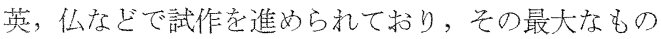
汢英国の Appleton の属する IRD 社が進めている $3,250 \mathrm{PP}$ の直流単極電動機である。彼はスライドを使 用この $3,250 \mathrm{IP}$ 機の開発状況を詳細に報告し，本機は 英国電力公団の火力発電所の揚水ポンプ用モーターと して本年秋には運転に入ると述べた。またこの試作経 験を下に 8,000円, $50 \mathrm{rpm}$ 機を例にとり, 超電尊機の 方が現用機よりも既に有利で西り，直流機への超電導 の応用は極めて魅力的であると結論した。彼の言によ
れば，上記の比較結果は第 1 表のようになるとのこと で, 価格, 重量, 効率いすれも超電導機は有利だとい うことになる。

第 1 表 $8,000 \mathrm{P}, 50 \mathrm{rpm}$ 直流機の比較

\begin{tabular}{|c|c|c|c|}
\hline 諸元 & 種類 & 普 通 形 & 超 電 導 形 \\
\hline 重 & 量 & 370 ton & 25 ton \\
\hline 価 & 格 & $£ 220,000$ & $£ 130,000$ \\
\hline 效 & 率 & $94 \%$ & $97 \%$ \\
\hline
\end{tabular}

この外上記のように, 冷凍機, 交流損, 低温構造材 料などが各講師から報告されたが，我々には比較的 なじみ少ない欧州のこの種技術が，米国のそれと比較 して極めて高いレベルにあり，物によっては欧州の尤 が勝っているのではないかと考光るほどの内容であっ た。

\section{（2）普通講演の内容}

この関係注講演の題目を全部述べことは紙数の都 合上無理であるので分類別に論文数を下記に示してお <。
(a) 電力と LNG（液化天然ガス） $\times 1$ 件
(b) 直流送電
$\times 3 "$
(c) 交流送電
(d) 送電線付带設備
$\times 8 "$
(e) 機 器
$\times 3 \prime \prime$
$\times 7 "$
(f) 超電導線
$\times 3 \prime$
(g) 極低温技術
$\times 2 \prime$
(h) へリウムの極低温電気特性
$\times 2 \prime$
(i) 熱伝達
$\times 3 \prime$
(j) エネルギー蓄積装置
$\times 4 \prime \prime$

上記のうち(a)，(b)，(c)，(d)は電力送電の問題であり (h) ( j) も関連が深いことを考えると, 提出論文 36 件のう ち半数以上が送電問題 (超電導ケーブル) で, 特別講 演を含めて, 欧米の電力会社がこの問題に如何に関心 が樑いかを知ることが出来る。従来各種の超電導ケ一 ブルの案が出されていたが, そのほ上んどが送電容量 10 100 GW といらような大容量の直流ケーブルのみ で，多少現実離れしていたが，今回の会議に提出され たもの注流 3 件, 交流 8 件, 送電容量も $1 \mathrm{GW}$ 程 度と極好現実的なものが提出されている。なかでも 英国電力公団のグループが提出した超電導ケーブル は, 送電容量 $750 \mathrm{MW}$, 送電電圧 $33 \mathrm{kV}, \quad \mathrm{BIL}=190$ $\mathrm{kV}$ と極めて具体的な内容のもので, 超電導ケーブル 近しの感与考た。

機器の関倸では上記 $3,250 \boxplus$ 機の直接担当者からさ 低温工学 
らに詳しい報告や発電機, 变圧器, 整流機, エネルギ 一蓄積装置などがあり，小生も当時試作中であった10 $\mathrm{kW}$ 直流機を発表した。これらのらら直流機它除いて は未来像や案を示守内容などがほとんどで，実用には 未だ多少距離があるといら感じであった。

あとがき

この会議老通じて感じたことは，わが国では大学や
研究所の域党あまりこえていない超電導技術が，欧米 では既に電力会社や製造者の関係者が現実に近いもの として可成り具体的に問題点を追及しており,幅広く, 深い層で関心を持たれ始めたことである。わが国でも 超電導技術が大容量, 高性能を要求する未来技術に十 分な担手の資格のあることを認識し，今より十分な手 它打つ必要があることを痛感した。

$=$ I - ス

\section{Cryo/'70}

Cryogenic Society of America, lnc. 主催の Cryo/'70 は Cryogenic Technology Clinics と 6th Annual Cryogenic Equipment Exposition 連合したもので，5月25〜27日 Chicago-Sheraton Hotel にて開催される。

Cryo/'70 のテーマは「Cryogenics：㐋の応用と装 置」で，仮要目は下記のとうり。

Processes and Process Equipment, Part 1

Air Separation Processes

Liquid Hydrogen Processes

Liquid Helium Processes

LNG Processes

Petrochemical Processes

Processes and Process Equipment, Part II Expanders: Types, Applications and Design Cold Gas Compressors : Types, Applications and Design

Heat Exchangers: Types, Applications and Design

Pumps: Types, Applications and Design

Instrumentation: Types, Applications and Design

Small Cryogenic Liquid Bulk Stations

Types, Method of Supply and Site Standards
Marketing Advantages and Operation

Economics

Care, Maintenance and Repair of Stations and Supply Units

Construction and Insulation Materials

Portable Cryogen Containers

Types and Applications, Present and Future

Filling, Transporting and Dispensing

Instruments for Performing Tasks

Medical Instruments

Laboratory Instruments

"Cryorganics"

Food Freezing, Storage and Distribution

Food Processes Other Than Freezing

Animal Breeding

Other Cryobiology Applications

Elastomers, Sealants and Lubricants 連絡先

Cryo/'70

Robert T. Kenworthy, Inc.

Exposition Management

866 United Nation's Plaza

New York, N.Y. 10017

U.S.A. 